\title{
Decision Making Remaja Melakukan Aborsi pada Kehamilan di Luar Nikah
}

\author{
Edelwis Tiara Poespa Mayendri ${ }^{1}$, Edi Prihantoro ${ }^{2}$ \\ 1,2Universitas Gunadarma, Jakarta - Indonesia
}

\begin{abstract}
ABSTRAK
Krisis pengetahuan tentang edukasi seksual membuat para remaja pelaku aborsi kurang mengetahui bahaya aborsi dan kurang memahami boleh dan tidaknya melakukan aborsi. Proses pengambilan keputusan pelaku aborsi pun berbeda. Minimnya pengetahuan dan terjerumus dalam pilihan yang sulit, membuat pelaku melakukan hal yang tidak seharusnya dilakukan saat memutuskan aborsi. Penelitian ini menggunakan pendekatan kualitatif, menggunakan teori pengambilan keputusan sebagai pisau analisis. Penelitian ini dilakukan mengingat tingkat aborsi di Indonesia masih tinggi, dan kematian ibu akibat aborsi menjadi keprihatinan. Pendekatan penelitian ini menggunakan Fenomenologi untuk mengidentifikasi dan mengungkap makna dibalik cara pengambilan keputusan pada pelaku aborsi, sehingga yang ditonjolkan adalah proses pengambilan keputusan melakukan aborsi illegal.
\end{abstract}

Kata kunci: aborsi, pengambilan keputusan, pelaku aborsi

\section{Decision Making of Adolescent in Committing Abortion for Extra-Marrital Pregnancy}

\begin{abstract}
Lack of sexual education is the main reason for adolescents commiting abortion unaware about the danger of abortion and understanding on whether or not it is permissible to commit abortion. Decision making process of the adolescents who commit abortion is varied. The lack of knowledge and the difficult situation they are facing are the reasons for the adolescents in taking the decision to abort the pregnancy. This study uses a qualitative research method and uses the theory of Decision Making as a knife analysis in Decision Making: Abortion Practices in the Millennial Era. This case was taken in view of the very high abortion rate in Indonesia, and maternal deaths due to abortion that are of concern. So this research approach uses the Phenomenology approach to find out Decision Making: Abortion Practices in the Millennial Era. Phenomenology seeks to identify the meaning behind the method of decision making for abortionists, so what is highlighted is the abortion decision making process.So this research approach uses the Phenomenology approach to find out Decision Making: Abortion Practices in the Millennial Era. Phenomenology seeks to identify the meaning behind the method of decision making for abortionists, which highlights the abortion decision making process.
\end{abstract}

Keyword : abortion; decision making; abortionist 


\section{PENDAHULUAN}

Aborsi menjadi jalan bagi perempuan yang hamil di luar nikah untuk menggugurkan kandungannya secara tidak sah dan melanggar hukum. Melakukan aborsi pun tidak sulit, sebab tersedia banyak informasi, lengkap dengan link atau website yang memuat perihal aborsi. Media online juga tidak henti-hentinya menyediakan informasi dan menjadi jalan bagi pencarian melakukan aborsi.

Maraknya peminat aborsi membuat munculnya penawaran illegal untuk menggugurkan kandungan. Sebuah klinik di Jalan Paseban, misalnya, telah menggugurkan 903 janin (CNN Indonesia). Praktik aborsi itu dilakukan oleh dokter dan bidan dan telah beroperasi selama 21 bulan. Tercatat ada 1.632 pasien yang mendatangi klinik di Jakarta Pusat itu.

Fenomena aborsi menjadi perhatian karena tingginya angka kematian ibu melahirkan yang mencapai 228 per 100 ribu kelahiran hidup. Dari jumlah tersebut, kematian akibat aborsi mencapai 30 persen. Pelaku aborsi leluasa dapat melakukan niatnya karena adanya iklan aborsi baik memalui website, blog dan media sosial.

Hasil survei yang dilakukan oleh Worlddometer, American Library Association (ALA), kematian karena perbuatan aborsi mencapai 41,9 juta orang selama 2018, sedangkan kematian akibat penyakit kanker hanya 8,2 juta orang, kemudian lima juta orang juga meninggal karena asap rokok dan 1,7 juta orang meninggal karena penyakit HIV/AIDS.

Data tersebut berdasarkan data global berkerjasama dengan World Health Organization. Jika dikombinasikan dengan kematian karena kanker, rokok, alkohol, bahkan akibat kecelakaan lalu lintas, ternyata kematian karena perbuatan aborsi jauh lebih unggul. Tingkat kematian bayi atau janin akibat aborsi sudah menjadi angka yang mengkhawatirkan.

Pernikahan di usia muda, hamil di luar nikah merupakan alasan utama para pelaku aborsi melakukan tindakannya. Bahaya melakukan aborsi tidak diketahui banyak oleh para pelaku. Minimnya pengetahuan inilah yang membuat tingkat aborsi terus bertambah.

Menurut Siagian (dalam Asnawir, 2006), pengambilan keputusan merupakan suatu pendekatan yang sistematis terhadap suatu masalah yang dihadapi. Menurut Salusu (2004), pengambilan keputusan adalah suatu proses memilih alternatif cara bertindak dengan metode yang sesuai dengan situasi. Sedangkan Jannis \& Mann (1977) menyebut pengambilan keputusan merupakan pemecahan masalah dan terhindar dari faktor situasional.

Mengenai proses pengambilan keputusan, Harris (1998) menyatakan merupakan proses non linier dan recursive (berulang), artinya proses pengambilan keputusan tidak selamanya melalui aliran yang konstan. Sebaliknya, kebanyakan keputusan dibuat setelah melalui pertimbangan berulang-ulang. Tahapan tertentu akan dilalui dalam waktu singkat sementara tahapan lain memerlukan waktu lebih lama dan pertimbangan yang lebih kompleks. Adair (2007) menambahkan dalam serangkaian tahapan pengambilan keputusan, tidak harus semua tahapan dikuti secara kaku pada setiap situasi. 
Dalam suatu pengambilan keputusan, karakterisitik pengambil keputusan akan mempengaruhi hasil keputusan yang dibuat. Russel-Jones (2000) menjelaskan suatu pengambilan keputusan merupakan proses yang melibatkan kemampuan kognitif yang dipengaruhi usia, jenis kelamin, tingkat pendidikan, sikap dan nilai-nilai yang dimiliki. Pengambilan keputusan membutuhkan kemampuan analisis penyelesaian masalah dan penilaian masalah.

Individu cenderung membuat keputusan yang salah karena sebelumnya tidak menganalisa penyebab diambilnya keputusan tersebut. Seringkali kita lebih memfokuskan pada symptom yang terlihat di depan mata. Konteks situasi dari keputusan yang diambil akan sangat mempengaruhi proses pengambilan keputusan. Dalam hal ini tidak mungkin mengabaikan kondisi sekitar kita saat mengambil suatu keputusan.

Kesulitan yang umum terjadi dalam suatu proses pengambilan keputusan adalah kurangnya pilihan yang memungkinkan untuk diambil, khususnya ketika tidak satupun diantara pilihan tersebut sesuai dengan tujuan pengambilan keputusan. Untuk mengatasi hal ini, dapat dilakukan dengan brainstorming bersama orang lain atau berkonsultasi dengan professional.

Setiap keputusan yang diambil akan menghasilkan suatu konskuensi, dan tidak akan ada artinya keputusan tersebut jika individu tidak berkomitmen terhadap konskuensinya. Atas dasar hal tersebut, harus dianalisa konskuensi yang paling sesuai dengan kebutuhan individu sehingga ia mampu menjalaninya. Seringkali karena kesulitan dalam memilih dan tidak berani menghadapi konskuensi dari pilihan, individu memilih menghindar, tidak melakukan apapun.

Pada dasarnya tidak melakukan apapun tetaplah sebuah keputusan. Untuk mengatasi kesulitan ini, individu dapat menekankan pada dirinya bahwa proses pengambilan keputusan bukanlah memilih antara benar dan salah, akan tetapi memilih antara yang benar dan benar, tergantung pada persepsi pribadi. Pada satu titik setelah keputusan diambil, individu tetap harus menelaah ulang keputusan yang telah diambilnya. Frekuensi dan kedalamannya tergantung dari seberapa besar keputusan tersebut mempengaruhi kebutuhannya. Setelah keputusan diambil, sebuah tindakan harus dilakukan sebagai bentuk impelementasinya. Tidak akan ada artinya proses pengambilan keputusan yang sudah dilalui apabila individu tidak membuat suatu tindakan apapun.

Beberapa keputusan yang diambil pelaku aborsi bisa saja dianggap kurang penting yang hanya membutuhkan sedikit pemikiran. Sebaliknya ada keputusan yang dianggap penting yang membutuhkan pemikiran aktif untuk mencapai hasil yang memuaskan. Suatu keputusan dianggap penting karena berbagai alasan, diantaranya materi yang harus dikeluarkan dan konsekuensi dari keputusan tersebut. Selain itu, suatu keputusan juga dianggap penting jika berkaitan dengan opini tertentu atau nilai-nilai emosional dari si pengambil keputusan.

Penting atau tidaknya suatu keputusan akan berpengaruh terhadap involvement si pengambil keputusan, sehingga berkaitan dengan motivasi seseorang yang nantinya akan mempengaruhi usaha kognitif serta strategi yang digunakan untuk memecahkan masalah tersebut. Artinya, proses pengambilan keputusan tidak selamanya melalui suatu aliran yang konstan. Sebaliknya, kebanyakan keputusan dibuat setelah melalui pertimbangan berulangulang dan bolak-balik. 
Adapun aborsi dari sudut pandang hukum, agama, maupun kode etik kedokteran merupakan perbuatan terlarang. Seorang dokter tidak diperbolehkan melakukan tindakan aborsi atau pengguguran kandungan tanpa alasaan medis yang kuat. Ada beberapa macam aborsi seperti abortus spontan (abortus spontaneus), abortus terapeutik/medis (abortus provocatus therapeticum) dan abortus buatan (abortus provocatus criminalois).

Penelitian ini membahas aborsi abortus provocatus criminalois. Abortus provokatus kriminalis merupakan aborsi yang sengaja dilakukan tanpa adanya indikasi medik dan merupakan perbuatan kriminal. Biasanya pengguguran dilakukan dengan menggunakan alat-alat atau obat-obat tertentu.

Menurut UU Kesehatan Nomor 23 Tahun 1992, dalam keadaan darurat, dalam upaya untuk menyelamatkan jiwa ibu hamil dan atau janin, dapat dilakukan tindakan medis tertentu, salah satunya melalui aborsi. Selain pengertian itu, disebutkan pula aborsi atau pengguguran kandungan adalah terminasi (penghentian) kehamilan yang disengaja (abortus provocatus).

Sebanyak 52 persen anak muda Indonesia berpikir berhubungan seksual untuk pertama kali tidak menyebabkan kehamilan, sehingga mereka merasa aman-aman saja melakukan hubungan seksual. Pada kenyataannya tidak demikian. Ketika terjadi kehamilan, mereka melakukan aborsi. Suryo Darmono dari Rumah Sakit Carolus mengatakan tindakan aborsi dilakukan mendadak tanpa sepengetahuan orangtua pelaku aborsi. Alhasil, pelaku aborsi perempuan menjadi traumatik dengan tindakan aborsi (Abrori, 2014).

Saat ini pelaku aborsi masih marak. Jika ditelusuri, banyak tersedia iklan yang menawarkan obat-obatan aborsi, bahkan disertai dengan testimoni. Tidak jarang juga ada yang menjual melalui media sosial.

Penelitian terdahulu terkait pengungkapan diri remaja pelaku aborsi kepada orangtua, menyatakan, terdapat faktor rasa ingin tahu yang lebih sehingga remaja tidak ragu untuk mencoba hal-hal baru, termasuk melakukan hubungan seks di luar nikah yang berujung pada aborsi (Mayyasya, 2018). Rasa ingin tahu menjadi faktor utama untuk melakukan hubungan seks. Lantas bagaimana proses pengambilan keputusan dari pelaku aborsi, dan bagaimana cara dia melakukan niatnya untuk melakukan aborsi? Peneliti tertarik untuk mengungkap makna bagaimana proses pengambilan keputusan pelaku aborsi, sehingga didapat novelty cara mencegah perbuatan aborsi.

\section{METODE PENELITIAN}

Jannis \& Mann (1977) menyebutkan pengambilan keputusan merupakan pemecahan masalah dan terhindar dari faktor situasional. Dalam penelitian ini pengambilan keputusan ditempatkan pada paradigma konstruktivis; berusaha untuk mengungkap sebuah makna dibalik motif dan faktor pelaku aborsi melakukan aborsi. Bagaimana pelaku aborsi mengambil keputusan bisa diketahui dengan pendekatan fenomenologi. Data dikumpulkan melalui penelitian lapangan secara online (online field research) yaitu via chatting dan telepon. 
Penelitian ini menggunakan metode penelitian kualitatif. Penelitian kualitatif berusaha menjelaskan makna tentang suatu fenomena berdasarkan pandangan-pandangan partisipan. Penelitian yang dilakukan pada kondisi objek yang alami, peneliti sebagai instrumen kunci, teknik pengumpulan data dilakukan secara gabungan, data yang dihasilkan bersifat deskriptif, dan penelitian ini lebih menekankan makna dari pada generalisas.

Teori Pengambilan Keputusan dengan paradigma konstruktivis akan mengajukan pertayaan tentang bagaimana proses pengambilan keputusan dari pelaku aborsi. Teori ini cocok untuk dipadupadankan dalam memaknai dan menemukan bagaimana proses pengambilan keputusan dari pelaku aborsi dengan pendekatan fenomenologi dengan tujuan mengurangi terjadinya aborsi illegal.

\section{HASIL DAN PEMBAHASAN}

Aborsi adalah penghentian atau penggagalan kehamilan atau pengguguran anak dalam kandungan dengan menggunakan cara melawan hukum, sedangkan abortus adalah gugurnya anak yang ada di dalam kandungan karena kelahiran sebelum waktunya tanpa adanya unsur kesengajaan (Utami, 2015).

Survei yang dilakukan oleh Worlddometer, American Library Association (ALA), kematian karena aborsi mencapai 41,9 juta tahun 2018, sedangkan kematian akibat penyakit kanker hanya 8,2 juta orang, kemudian lima juta orang juga meninggal karena asap rokok dan 1,7 juta orang meninggal karena penyakit HIV/AIDS.

Pernikahan muda dan hamil di luar nikah merupakan alasan utama para pelaku melakukan aborsi tanpa memperdulikan bahaya yang dihadapi. Perbuatan kriminal tersebut umumnya dilakukan tanpa sepengetahuan orang tua. Akibatnya, aborsi terus terjadi dan semakin subur dengan tersedianya informasi tentang aborsi lengkap dengan harga obat-obatan serta alur distribusinya.

Pelaku aborsi dapat mengakses informasi melalui situs online sebagaimana dilakukan informan AP, seorang mahasiswi berusia 22 tahun; IF (22 tahun); dan OS (22 tahun). Proses pengambilan keputusan untuk melakukan aborsi yang dilakukan ketiga informan tersebut menjadi fokus pembahasan penelitian ini. Menurut Jannis \& Mann (1997, terdapat lima tahapan dalam proses pengambilan suatu keputusan, yaitu:

(1) Menilai Masalah. Hal ini dapat dilakukan dengan cara mencari informasi atau kejadian yang dapat memberikan pengaruh positif atau negatif bagi tindakan yang diambil. Selain itu harus ditentukan tujuan yang ingin dicapai dalam mengambil keputusan. Ada beberapa faktor yang dapat mempengaruhi penilaian masalah pada tahap ini yakni sumber masalah, kejelasan masalah serta kepribadian dan mood individu ketika menilai masalah tersebut. Pertanyaan yang sering muncul adalah: "Adakah risiko serius yang akan muncul jika saya tidak melakukan perubahan?" Informan AP (22 Tahun) memberi jawaban atas pertanyaan tersebut.

"pasti ada pengorbanan di masa kini dan yang akan datang, tapi ini jalan keluar dengan resiko yang besar. Resiko yang muncul apabila tidak melakukannya adalah dimarahin orangtua, 
putusnya kerja, dan putus kuliah. Resiko yang muncul apabila melakukannya adalah trauma, stress, takut"

Informan AP menyatakan telah melalui tahap penilaian terhadap masalah dengan mencari informasi bagaimana cara menggugurkan kandungan dengan resiko apapun. Dia menempuh resiko itu lantaran tidak ingin kedua orangtua marah dan kuliahnya terputus. Di pun mengambil keputusan melakukan aborsi.

Atas pertanyaan serupa, informan NF mengatakan ada resiko yang akan muncul jika dia melakukan aborsi. NF menjawab sebagai berikut

"Ini merupakan jalan keluar, tidak bisa ditunda karena takut perut semakin besar. Perlu mengambil keputusan ini karena tidak ada alternatif lain. Resiko serius yang muncul apabila melakukannya yaitu bisasaja saya jadi mandul"

Informan NF sudah mengetahui resiko yang akan dihadapinya. NF bahkan sudah melakukan aborsi sebanyak tiga kali yang membuat rahimnya terancam mandul, namun perbuatan ini tetap dia lakukan. Mengandung di luar nikah, dengan status mahasiswa membuat NF memutuskan melakukan aborsi. Dia takut kehamilan diketahui orangtuanya. NF pada akhirnya melakukan aborsi dan mengakhiri hubungan dengan pasangannya.

Informan OS, juga seorang mahasiswi, mengatakan sudah paham atas resiko yang akan dihadapi saat memutuskan melakukan aborsi.

"iya saya takut menggugurkan bayi akan berdampak pada kehamilan saya nantinya. Resiko yang akan muncul apabila tidak melakukan aborsi adalah saya akan putus kuliah begitu juga pasangan saya dan nama baik keluarga saya, apalagi keluarga tidak ada yang tau. Nama baik keluarga akan buruk sekali. Resiko yang muncul adalah rasa sesal tidak pernah hilang setelah melakukannya"

Informan OS sudah paham akan resiko yang akan dihadapinya, terlebih lagi usia kandungan sudah tujuh bulan saat ia melakukan aborsi. Orang tuanya sudah mengetahui kehamilan illegal tersebut. Berdasarkan penelusuran, informan OS sudah memahami apa yang terjadi pada dirinyan namun OS tetap memutuskan melakukan aborsi.

(2) Mencari alternatif-alternatif yang ada. Setelah individu yakin terhadap setiap informasi berkaitan dengan masalahnya, dia dapat memusatkan perhatian pada berbagai alternatif pilihan yang tersedia. Hal ini juga dapat dilakukan dengan mencari masukan dan informasi dari orang lain yang memiliki pengetahuan yang berhubungan dengan masalahnya. Hal terpenting pada tahap ini adalah sikap terbuka dan fleksibilitas sehingga individu tidak akan kekurangan alternatif pilihan. Pertanyaan yang paling sering muncul adalah: "Apakah saya telah melihat dan mempertimbangkan seluruh alternatif yang ada?"

Saat Informan AP diberi pertanyaan apakah sudah mencari alternative lain?; apakah sudah mencari informasi atau masukkan dari orang lain yang memiliki pengetahuan tentang itu?; apakah sudah mempertimbangkan seluruh alternatif yang ada ?, dan pilihan apa saja yang anda miliki? Informan AP menjawab sebagai berikut:

"Saya tidak mencari alternatif lain, tapi mencari informasi atau masukan dari sahabat dekat. Saya sudah mempertimbangkan seluruh alternatif yang ada, pilihan yang dimiliki menggugurkan kandungan, menikah, merawat kandungan atau menikah tapi pas lahir anaknya diasuh orangtua" 
Informan AP sudah berani terbuka dengan sahabatnya, bercerita tentang masalah yang dihadapinya, namun tidak ada alternatif selain menggugurkan kandungan demi masa depannya. Pada mencari alternatif lain dalam mengambil keputusan, AP merasa sudah melakukan hal yang menurutnya tepat sebelum melakukan aborsi.

Informan NF turut diberikan pertanyaan yang sama dan menjawab sebagai berikut:

"tidak mencari alternatif lain, tidak mencari masukkan dari orang lain. Tidak mempertimbangkan alternatif apapun, pilihan yang dimiliki hanya aborsi"

Terhadap pertanyaan serupa, informan OS menjawab sebagai berikut:

"tidak ada alternatif lain selain aborsi. Ada yang minta saya melahirkan ada yang minta saya menggugurkan. Sudah mempertimbangkan seluruh alternatif yang ada. Pilihan yang saya miliki, pindah ke rumah kos-kosan, lari dari rumah dan aborsi"

Pada tahap ini informan OS sudah meminta saran dari temannya, namun OS bingung dalam mengambil keputusan sehingga mempunyai rencana yang lain, namun predisposisi dari OS yang cenderung kasihan kepada keluarga dan pasangannya membuat OS memutuskan melakukan aborsi.

(2) Mempertimbangkan setiap alternatif. Pada tahap ini, individu mengevaluasi setiap pilihan yang ada berdasarkan konskuensinya dan kemungkinan untuk dapat dilakukan atau tidak. Dasar pertimbangan biasanya adalah manfaat atau pengorbanan di masa mendatang. Ketika ia menyadari adanya penyesalan, maka akan semakin hati-hati dalam menimbang setiap alternatif yang tersedia. Pada tahap ini biasanya muncul ketidakpuasan atas tindakan yang sudah dilakukan, berusaha menghindar melakukan tindakan karena tidak ingin konsekuensi yang diambil responsif terhadap informasi baru yang memungkinkan keputusan berubah. Pertanyaan yang biasa muncul adalah: "Alternatif apa yang terbaik bagi saya?"

Informan AP sudah mencari alternatif dan bercerita kepada temannya. AP juga menyatakan alternatif terbaiknya adalah melakukan aborsi. Begitu juga Informan NF dan OS yang berpikir aborsi adalah alternatif terbaik, meskipun narasumber OS sempat berubah pikiran untuk merawat anaknya. Namun karena tidak mau, dan malu serta pasangannya belum siap, OS memutuskan untuk mengugurkan kandunganya.

(3) Membuat Komitmen.Tahap ini adalah tahap yang penuh dengan ketegangan. Individu dihadapkan pada berbagai pilihan yang sudah dianalisa, ditelaah dan harus membuat keputusan tentang pilihan yang akan diambil. Hal ini hanya dapat diakhiri dengan membuat keputusan dan berkomitmen terhadap keputusan tersebut. Seringkali individu memberitahu keputusannya pada orang lain, terutama orang-orang yang berada dalam jaringan sosialnya. Dengan demikian tahap ini dipengaruhi oleh orang-orang atau kelompok yang dianggap penting bagi si pengambil keputusan. Pertanyaan yang paling sering muncul adalah: "Kapan mengimplementasikan alternatif terbaik dan membiarkan orang lain tahu keputusan saya?"

Informan AP mengatakan sudah mempunyai pilihan yaitu aborsi. Tegang dan takut dalam memutuskan untuk melakukan aborsi, terlebih lagi AP becerita kepada sahabatnya untuk melakukan aborsi. Temannya mendukung AP melakukan aborsi sehingga AP dapat berkomitmen dan mengambil keputusan melakukan aborsi. 
Informan NF mengatakan hanya aborsi yang menjadi pilihannya. Untuk memutuskan aborsi pun di diliputi rasa takut dan cemas bahkan sampai ingin bunuh diri. AP menggugurkan kandungannya, didukung oleh pasangannya yang masih kuliah. Orang tuanya belum tahu di hamil di luar nikah, dan itu menjadi ketakutan terbesarnya. Hal ini yang membuat NF yakin dan memutuskan untuk melakukan aborsi.

Informan OS mengatakan ia pada awalnya ingin mempertahankan kandungan, terlebih teman-temannya mendukung untuk mempertahankan kandungannya. Namun dengan penuh rasa bimbang dan takut serta dan stress, OS memutuskan melakukan aborsi demi orangtua, dan pasangan yang belum siap menikah di usia dini.

(4) Konskuen terhadap komitmen meskipun memperoleh umpan balik negative. Setiap keputusan yang diambil seseorang tentu memiliki risiko negatif. Akan tetapi yang penting adalah tidak bereaksi berlebihan terhadap kritik atau kekecewaan yang mungkin muncul. Hal ini pasti terjadi pada mereka yang melakukan aborsi. Resiko besar mulai dari nama baik keluarga, nama baik diri sendiri dan resiko fisik maupun mental akan sangat berpengaruh. Namun ketiga informan berhasil melewatinya dengan tidak bereaksi berlebihan terhadap kekecewaan yang muncul.

Tahapan Pengambilan Keputusan. Menurut Russel-Jones (2000), ada tujuh tahapan dalam suatu pengambilan keputusan sebelum individu melakukan tindakan. Tahapan-tahapan tersebut adalah sebagai berikut:

(1) Membuat batasan tentang keputusan apa yang harus diambil. Individu cenderung membuat keputusan yang salah karena sebelumnya tidak menganalisa penyebab diambilnya keputusan tersebut. Seringkali kita lebih memfokuskan pada simptom yang terlihat di depan mata. Pertanyaan yang sering muncul adalah: "mengapa saya mengambil keputusan ini?" "Apa tujuannya mengambil keputusan ini?"

Informan AP telah melakukan aborsi satu kali. Ia melakukan aborsi demi masa depannya yang lebih baik, walaupun dia tahu aborsi menghadapi resiko besar. Informan AP menjalani hidupnya seperti biasa, meskipun dia tahu apa yang dilakukannya itu adalah hal yang salah namun melegakan hatinya. Namun AP tetap melakukan aborsi tanpa memikirkan ia membunuh janin yang ada dalam kandungannya.

AP mengatakan aborsi ini dimulai dari adanya nafsu birahi sexual dan mempercayai pasangannya. Faktor inilah yang menjadikan masa depannya menjadi taruhan. Faktor tersebut banyak dialami pelaku aborsi: terlena dengan omongan dan janji-janji manis pasangan.

Informan IF telah melakukan aborsi tiga kali. Dia mengatakan menggugurkan kandungannya karena tidak ada jalan atau alternatif lain. IF juga mengetahui resiko besar yang mungkin dihadapinya yaitu mandul. IF juga sempat ingin bunuh diri sebelum melakukan aborsi.

Informan OS melakukan aborsi saat kandungannya berusia lima bulan. Dia mengatakan mengambil keputusan ini karena berfikir masa depan yang masih panjang, dan tidak siap memiliki anak dan menikah. Sebelumnya OS sudah menyiapkan nama dan perlengkapan bayi, 
namun kedua orang tua OS tidak setuju apabila OS menikah dan mempunyai anak. Itu sebabnya OS mengugurkan kandungannya.

(2) Memahami konteks situasi dimana keputusan akan dibuat. Konteks situasi dari keputusan yang diambil akan sangat mempengaruhi proses pengambilan keputusan. Kita tidak mungkin mengabaikan kondisi sekitar kita saat mengambil suatu keputusan. Pertanyaan yang mungkin muncul adalah: "siapa-siapa saja yang berperan dalam proses pengambilan keputusan ini?" "Kepada siapa saja dampak keputusan ini akan berpengaruh?

Informan AP mengatakan dia hanya memberitahu teman terdekatnya saja. AP juga mengatakan dampak besar yang akan ia alami bila tdak mengambil keputusan tersebut. AP juga menyebut akan kehilangan kepercayaan dari kedua orangtuanya bila tahu ia hamil di luar nikah.

Informan IF mengatakan yang berperan saat mengambil keputusan abosri adalah dia sendiri Bersama pasangannya. IF pun juga mengatakan masa depannya menjadi taruhan. IF juga mengatakan apa yang dilakukannya akan berdampak pada masa depannya. Pendidikan dan keluarga menjadi prioritas, sehingga keputusan untuk melakukan aborsi adalah satu-satunya cara untuk dapat mencapai masa depan yang lebih baik.

Informan OS mengatakan yang berperan dalam memutuskan aborsi adalah ia Bersama teman-teman dan pasangannya. OS mengatakan apa yang dia lakukan bisa berdampak pada masa depan, pasangannya, dan membuat malu keluarga bila ketahuan hamil di luar nikah. Oleh sebab itu OS memutuskan melakukan aborsi.

(3) Mengidentifikasi setiap pilihan yang ada. Kesulitan yang umum terjadi dalam suatu proses pengambilan keputusan adalah kurangnya pilihan untuk diambil, khususnya ketika tidak satupun diantara pilihan tersebut sesuai dengan tujuan pengambilan keputusan. Untuk mengatasi hal ini, dapat dilakukan brainstorming bersama orang lain atau berkonsultasi dengan profesional. Pertanyaan yang sering muncul adalah: "Pilihan-pilihan apa saja yang saya miliki. Apakah langkah ini merupakan jalan keluar?"

Hasil wawancara dengan informan AP mengatakan langkah melakukan aborsi adalah langkah terbaik. AP juga mengatakan pasti ada pilihan lain, tetapi karena sudah stress dan banyak hal yang dipikirkan, AP pun memutuskan melakukan aborsi.

Informan IF mengatakan tidak mencari alternatif lain selain melakukan aborsi untuk mencapai masa depan yang lebih baik. Aborsi merupakan jalan keluar bagi IF untuk menyelesaikan permasalahan yang dihadapinya.

Wawancara dengan OS mengatakan, dia memiliki pilihan untuk melanjutkan kehamilan, namun pasangan dan kedua orangtuanya tidak dapat menerimanya. Faktor itulah ang membuat OS memutuskan untuk melakukan aborsi. OS juga mengatakan sudah berencana untuk mengontrak rumah, namun saat OS berpikir masa depannya masih panjang dan orangtuanya malu dia menikah di usia dini serta belum siap mempunyai anak, membuat dia memutuskan melakukan aborsi. 
(4) Mengevaluasi konskuensi dari masing-masing pilihan. Setiap keputusan yang diambil akan menghasilkan suatu konsekuensi, dan tidak akan ada artinya keputusan tersebut diambil jika individu tidak berkomitmen terhadap konsekuensinya. Atas dasar hal tersebut, harus dianalisa konsekuensi yang paling sesuai dengan kebutuhan individu sehingga ia mampu menjalaninya. Pertanyaan yang sering muncul adalah pilihan mana yang konsekuensinya paling masuk akal dan sesuai dengan kebutuhan? Sejauh mana penyesalan yang akan terjadi jika saya mengambil tindakan dan tidak mengambil Tindakan tersebut?

Hasil wawancara dengan narasumber AP mengatakan kebutuhan terhadap masa depan yang cerah merupakan realitas, sehinga ia memutuskan melakukan aborsi. Namun begitu, AP tidak ingin melakukannya lagi dan menyesal atas perbuatannya.

Informan IF mengatakan ingin punya masa depan yang cerah, dan tidak ingin melakukannya lagi dan menyesal atas perbuatannya, begitu juga dengan informan OS yang ingin mendapatkan masa depan lebih baik. OS menyesal dan tidak ingin mengulangi perbuatannya.

(5) Menentukan prioritas dan memiliki satu diantaranya. Setelah setiap konsekuensi pilihan selesai dianalisa, kita harus memilih salah satu diantara serangkaian pilihan tersebut. Seringkali karena kesulitan dalam memilih dan tidak berani menghadapi konskuensi dari pilihan, individu memilih menghindar dengan tidak melakukan apapun. Pada dasarnya tidak melakukan apapun tetaplah sebuah keputusan. Untuk mengatasi kesulitan ini, individu dapat menekankan pada dirinya bahwa proses pengambilan keputusan bukanlah memilih antara benar dan salah, akan tetapi memilih antara yang benar dan benar, tergantung pada persepsi pribadi.

Dari hasil wawancara dengan ketiga narsumber, mereka memiliki prioritas yang sama yaitu kedua orang tua, keluarga dan masa depan yang cerah sehingga harus melakukan aborsi. Informan merasa apa yang mereka lakukan adalah benar demi tujuan masa depan.

(6) Menelaah ulang keputusan yang dipilih. Pada satu titik setelah keputusan diambil, individu tetap harus menelaah ulang keputusan yang diambil. Frekuensi dan kedalamannya tergantung dari seberapa besar keputusan tersebut mempengaruhi kebutuhannya. Ketiga informan sudah menelaah keputusan yang diambil dengan mempertimbangkan apa yang akan terjadi dan didapatkan apabila tidak melakukan aborsi.

(7) Mengambil tindakan terhadap keputusan yang dipilih. Setelah keputusan diambil, sebuah tindakan harus dilakukan sebagai bentuk impelementasinya. Tidak akan ada artinya proses pengambilan keputusan yang sudah dilalui apabila individu tidak membuat suatu tindakan apapun. Ketiga informan sudah melakukan aborsi dan memilih melakukan aborsi. Tindakan yang dipilih adalah melakukan aborsi. Informan sudah melakukan implementasi pilihannya: melakukan aborsi dengan cara masing-masing, mulai dari meminum obat hingga operasi.

\section{SIMPULAN}

Tindakan melakukan aborsi diambil para informan demi masa depan dan tidak membuat malu orangtua. Tingginya tingkat kepercayaan pada pasangan dan tidak berfikir panjang atas efek 
melakukan hubungan seksual di luar nikah akibat kurangnya edukasi seksual membuat pelaku terjebak dalam perbuatan melanggar hukum: melakukan aborsi. Orang tua harus meningkatkan edukasi seksual sejak dini bagi putra-putrinya agar terhidar dari pergaulan sex di luar nikah.

Proses pengambilan keputusan pelaku aborsi dilakukan melalui beberapa tahap, mulai dari secara sadar melakukan hubungan seksual di luar nikah, memahami keadaan fisik yang sedang hamil, memahami masalah dan resiko yang dihadapi, sampai dengan memutuskan untuk melakukan aborsi. Keseluruhan informan sudah menyesali perbuatannya, dan menyatakan menyesal atas perbuatan mereka. Para informan juga mengakui apa yang dilakukannya adalah hal yang salah dan berjanji tidak lagi mengulanginya.

\section{DAFTAR PUSTAKA}

Abrori. (2014). Di Simpang Jalan Aborsi. Semarang: Gigih Pustaka Mandiri.

Copelton, D.A. (2004), Menstrual Extraction, Abortion, and the Political Context of Feminist Self-Help. Emerald Group Publishing Limited, Bingley, 18: 129-164.

Harahap, R. A. (2019). Buku Ajar Komunikasi Kesehatan. Jakarta Timur: Prenademedia Group. Idrus, M. (2009). Metode Penelitian Ilmu Sosial, Yogyakarta: Erlangga.

Ikbar, Y. (2012). Metode Penelitian Sosial. Bandung: Refika Aditama.

Muhamad, F. (2017). Metodologi Penelitian: Penelitian Kualitatif, Bojong Genteng: CV Jejak. Junaedi, F. (2018). Komunikasi Kesehatan: Sebuah Pengantar Komprehensif. Jakarta: Prenademedia Group.

Maulana, H. D. (2009). Promosi Kesehatan. Jakarta: Buku Kedokteran EGC

McNeill, P. 2003. Research Methods, London, Rutledge.

Maulana, H. D. (2009). Promosi Kesehatan. Jakarta: Buku Kedokteran EGC.

McNeill, P. 2003. Research Methods, London, Rutledge.

Misra, R. (1998), Effect of age, gender and race on abortion attitude, International Journla of Sociology and Social Policy, 18: 94-118.

Muhadjir, N. (1989). Metodologi penelitian kualitatif. Yogyakarta: Rake Sarasin.

Mulyana, D. (2013). Metodologi Penelitian Kualitatif. Bandung: Rosdakarya.

Morissan. (2014). Teori Komunikasi, Jakarta, Prenamedia Group.

Pujileksono, S. (2015). Metode Penelitian Komunikasi Kualotatif. Malang: Kelompok Intrans Publishing.

R, D. S. (2016). Gambaran Keterbukaan Diri (Studi Deskriptif pada siswa kelas VIII di SMP Negeri 48 Jakarta). Jurnal Bimbingan Konseling, 52.

Susanti, Y. (2012). Perlindungan Hukum bagi Pelaku Tindak Pidana Aborsi (Abortus Provocatus) Korban Perkosaan. Syiar Hukum, 294. 